Portland State University

PDXScholar

Jul 25th, 10:45 AM - 11:45 AM

\title{
Leveraging Adult Learning Theory with Online Tutorials
}

\author{
Rebecca Halpern \\ University of Southern California \\ Chimene Tucker \\ University of Southern California
}

Follow this and additional works at: https://pdxscholar.library.pdx.edu/liw_portland

Part of the Information Literacy Commons

Let us know how access to this document benefits you.

Halpern, Rebecca and Tucker, Chimene, "Leveraging Adult Learning Theory with Online Tutorials" (2014). Library Instruction West 2014. 11.

https://pdxscholar.library.pdx.edu/liw_portland/Presentations/Publications/11

This Event is brought to you for free and open access. It has been accepted for inclusion in Library Instruction West 2014 by an authorized administrator of PDXScholar. Please contact us if we can make this document more accessible: pdxscholar@pdx.edu. 
LEVERAGING ADULT LEARNING THEORY WITH ONLINE TUTORIALS

\section{Introduction}

Conventional wisdom notes that the Internet has had the greatest impact on the field of librarianship. According to Sun et al. (2011, p. 323), "Web 2.0 is now playing a key role in promoting information accessibility by exploring information sharing and collaboration through the worldwide web." With the introduction of the Internet, as well as other information and communication technologies, institutions of higher education have begun offering courses and degree programs online. Allen and Seaman (2011, p.11) contend, "students at least taking one online course has increased at a rate far in excess of the growth for overall all higher education." Consequently, in the United States, Web 2.0 technology has had the greatest impact on adult learners and online learning (Allen and Seaman, 2011; Miller, 2014; Wyss, 2008).

Libraries recognize the changing technological landscape by adopting new services and resources, while at the same time continuing to provide many of the traditional services both students and faculty have grown to love. Hansen (2003, p. 1) states, "Academe in the 21 st century will continue to be an evolving world of traditional courses moving to an online format of virtual learning." Libraries are in a key position to support online learning (Miller, 2014). It follows, then, that the Internet and Web 2.0 technologies are key aspects in changes in librarianship.

The roles of librarians in the 21 st century are changing. Librarians take an active role in “online learning environments” (Walter, 2008). In other words, academic librarians today work both on the ground and in the cloud providing traditional face-to-face reference and library instruction, as well as virtual reference and library instruction.

There is a wealth of literature on the values of online tutorials for reference and instruction tools (Buehler et al., 2001; Gold, 2005; Gonzales, 2014; Larreamendy -Joerns and 


\section{LEVERAGING ADULT LEARNING THEORY WITH ONLINE TUTORIALS}

Leinhardt, 2006; Viggiano, 2005). For distance education, as noted by Zhang et al (2005, p.789), “online tutorials support has become an increasing popular method for students." Librarians use tutorials when teaching credit bearing courses (Arif and Mahmood, 2012; Newby, Eagleson, and Pfander, 2014; Shupe and Pung, 2011) or when collaborating with online teaching faculty to create and design research assignments (Burns et al., 2014; Jumonville, 2014). Instructorlibrarian collaborations emphasize the importance of student success in the online learning environment (Julien and Pecoskie, 2009; Massis 2012).

Given this shift in the profession towards online and digital learning tools, it is not surprising that librarians are at the forefront of change, protecting the rights of the users and ensuring access to information - not only through resources and collections, but through the meaningful interaction with those sources. Because non-traditional learners - be they adults, foreign-born students, or English as a second language students - are on our university campuses at an ever-growing rate (Parker, Leinhart and Moore, 2011), librarians must be proficient in providing instructional services to this population. Adult learners, defined according to the American Council on Education (2014), as students over the age of 25, learn differently than do more traditionally-aged university students, and they are a growing population on campuses across the country (Parker et al., 2011). Librarians and other educators have developed, and continue to develop, principles and best practices for engaging adult learners.

Students taking courses or completing their entire degrees online are one of the fastest growing populations in institutions of higher education, with $46 \%$ of students who have graduated in the last 10 years completing at least one online course (Parker et al., 2011). Online or distance education is not new, nor is the trend for distance programs to be heavily matriculated with adult students (Rossman, 2000). Distance learners historically, and continue to 


\section{LEVERAGING ADULT LEARNING THEORY WITH ONLINE TUTORIALS}

be, mostly adults: according to one study, "two-year (AA) institutions have historically been leaders in using distance courses to attract non-traditional students, and these institutions continue to pave the way in online course offerings to attract "post-traditional learners"' (Bischel, 2013, p. 3). In other words, programs that have historically catered to the adult or non-traditional learner have a richer infrastructure for supporting distance learning than do programs without a large adult student population. The reason adults tend to prefer online courses over on-theground courses are manifold, but among them is a distance program's promise of flexibility, so students are able to maintain employment and family responsibilities (Parker et al., 2011).

\section{Background and Context}

The University of Southern California (USC) has a growing number of online master's programs. The School of Social Work's Virtual Academic Center, and the Annenberg School of Journalism and Communication's online Master of Communication Management have, combined, approximately 500 new students per semester. The librarians who work with these programs are well-embedded in the online classroom: they frequently conduct information literacy sessions through the synchronous platforms, have virtual office hours, and host a number of recorded and live orientation sessions for incoming online students. In addition, because the librarians for these programs have been so successful in embedding information literacy into the curriculum, they provide informal leadership and guidance to librarian colleagues who are beginning to work with their own online degree students.

Online tutorials are an important component of the USC Libraries' instruction strategy because they serve a variety of uses. Online tutorials allow librarians to provide point-of-need instruction to students without relying on the course instructor to relinquish class time. Students who are non-native English speakers or who have a high level of information anxiety often rely 


\section{LEVERAGING ADULT LEARNING THEORY WITH ONLINE TUTORIALS}

on tutorials for questions, as a tutorial "never acquires an air of exhaustion when repeating basic information," and are helpful for the student who simply prefers a DIY approach to library research (Bowles-Terry, Hensley, and Hinchcliffe, 2010, p. 4). Subject librarians often embed video tutorials into LibGuides, and are often dispersed through various course management systems where appropriate. Tutorials are also used for instruction as part of a flipped classroom, or as in-class active learning exercises.

Furthermore, because online tutorials are considered a best practice for delivering distance library services (Viaggio, 2005), the librarians who work closely with distance programs rely on tutorials as orientation and introductory tools for our online students. According to institutional memory, when the tutorials were developed, both students and faculty enjoyed them. Despite USC having a variety of tutorials, and often using them systematically throughout distance programs, usage statistics and responses to user surveys indicate an overall decrease in usage by students who identify as being primarily online students.., To be clear, the existing tutorials were not interactive: they generally consisted of a short video either demonstrating a particular database or skill, or introducing library services. The authors contend that as distance programs gain popularity for adult learners, perhaps the underutilization of these tutorials was due to the structure of them not being appropriate for adult or nontraditional learners. Both online programs the authors liaison with have a higher percentage of nontraditional students than do their on-campus counterparts: for example, according to 2013 data available through the registrar, the average age of the on-campus MSW student is 28 , while the average age for the online student is 34 . Because of their unique demographics, the authors endeavored to create information literacy tutorials that are more aligned with adult learner pedagogy.

\section{Literature Review}




\section{LEVERAGING ADULT LEARNING THEORY WITH ONLINE TUTORIALS}

\section{Knowles' Theory of Andragogy}

Since Malcolm Knowles’ first book on adult learning theory was published in 1950, institutions of higher learning have considered how to meet the needs of adult learners on campus. Knowles began creating an alternative education model for adults when he noticed an unusually high dropout rate for adult education programs. Looking closely at the curriculum and instructional theories used in adult learning courses, he discovered that teachers continued to use pedagogical models, which assume "learners only need to know that they must learn what the teacher teaches," and that the learner's self-concept is a dependent receiver of information (Knowles, 1984, p. 53). Because adult learners were not afforded the opportunities to be selfdirecting, an important developmental need that comes with maturity, adults were dissatisfied with formal learning environments. Thus, Knowles concluded that "tensions, resistance, resentment, and often rebellion in the individual" towards formal learning was a result of the "the need and the ability to be self-directing” in educational settings (Knowles, 1984, p. 53).

Knowles' work identifies six assumptions of adult learners that comprise the principles of his andragogical model:.

1. "The need to know": The adult learner needs to know why she is learning something. Having a context for the value of a particular lesson can lead to self-direction, as the learner will have a clearer understanding of the benefits of learning the lesson and the "negative consequences of not learning it" (Knowles, 1984, p. 56). Framing a lesson within the learners' gaps in knowledge or skill, and clearly demonstrating why that gap needs to be closed, is the "first task of the facilitator" of adult learners.

2. "The learner's self-concept": Because adult learners have a strong self-concept and sense of independence, they may "resent and resist" educational settings where they 
feel the instructor is "imposing their wills on them." Of course, when a student is learning brand new material, a certain amount of traditional instruction is inevitable. Thus, this principle encourages the instructor to acknowledge the adult learners' need for self-conception and self-direction, and to balance pedagogical and andragogical strategies where appropriate (Knowles, 1984, p. 62). One of the greatest challenges for the instructor is designing and facilitating lessons in which "adults are helped to make the transition from dependent to self-directed learners" (Knowles, 1984, p. 57).

3. "The role of the learner's experience": Adult learners come to educational contexts with a host of work, life, and education experiences. An andragogical teacher will tap into that wealth of experience through experiential techniques, which confirms the adult learner's self-concept as self-directing and affirms their value as learners (Knowles, 1984, p. 57.)

4. "Readiness to learn:" Related to the first assumption, this assumption realizes that adults learn content better when it is situationally or psychologically appropriate. For instance, as given in Knowles (1984, p. 59), a worker would not be ready for supervisory training until she has mastered the area of which she would be supervising. Scaffolding lessons to meet the learner where she is, is an important assumption in the andragogical framework.

5. "Orientation to learning:" Adult learners are more capable of absorbing skills or lessons through problem-based or task-centered exercises. In other words, adults are oriented towards learning "when they are presented in the context of application to real-life situations" (Knowles, 1984, p. 59). 


\section{LEVERAGING ADULT LEARNING THEORY WITH ONLINE TUTORIALS}

6. "Motivation:" Unlike younger learners whose motivation to learn comes primarily from external factors, adults' motivation to learn comes from internal factors, such as goal-setting, career ambitions, or even just self-esteem (Knowles, 1984, p. 61).

It is important to note that while these six assumptions serve as the foundation for adult learning theory, it is not an exhaustive list of characteristics adult learners may have, nor is it intended to serve as a direct antithesis to pedagogy, or teaching for children. Instead, Knowles urges educators to recognize andragogy as "a model of assumptions, which includes pedagogical assumptions,” (Knowles, 1984, p. 62). In some learning contexts, pedagogical assumptions may be more realistic, regardless of the age of the students; likewise for instructing younger learners. Andragogy within Learning Theories

Andragogy manifests constructive learning theory through its precepts that adults be involved in their own instruction. Constructivist learning theory recognizes learning as both a social and reflective process. Constructivists understand that people create meaning through the interactions of prior experiences, knowledge, and introduction to new material (Anderman and Anderman, 2009). Constructivist educators facilitate learning through experiential strategies, such as creating a problem or conflict for learners to work though. Knowledge creation occurs through activities and exercises, and providing time for self-reflection in order for new knowledge to be incorporated into the learners' worldview. Constructivist approaches often blur the line between lecture and homework, and strive to make a learning environment studentcentered through experiential learning exercises (Merriam, 2001), peer-to-peer learning opportunities (Gold, 2004), contextualizing core concepts into real-world applications (Cooke, 2010; Rapchack and Behary, 2013), and the use of narrative techniques (Clark and Rossiter, 2008). 


\section{Applications of adult learning theory in LIS and education}

Because of the social and cognitive differences of adult learners as compared to their traditionally-aged counterparts, educators who are familiar with Knowles' work have developed an instructional framework that best facilitates adult learning. This framework, often called the Four Principles of Andragogy, suggests that adult-centered instruction:

1) be highly relevant to assignments,

2) be problem-based to encourage critical thinking and reflective learning,

3) acknowledge prior work and life experience, and

4) be self-paced (Ota, DiCarlo, Burts, Laird, and Gioe, 2006).

In particular, both library- and education-specific literature that tackles nontraditional students emphasize the need that adult students be highly involved in their own education. In an important work on facilitating adult learning in library instruction, Currie (2000, p. 222), argues that "adult learning is best facilitated when participants are engaged in the design of the learning...when the instructor acts as more of a facilitator...when the learner's experiences are utilized in the classroom, and when learning activities have direct relevance to the learner's circumstance." Currie goes on to posit that as educators, librarians should cultivate an adultcentered approach to library instructional design, and would incorporate elements of activitybased learning, inquiry-based learning, and self-directed learning approaches. Gold (2005) builds off Currie's work to suggest adult-centered library instruction include lessons and activities that are directly tied to an assignment or embedded into course curriculum. Gold also suggests that librarians be flexible in scheduling to include night or weekend reference or instruction opportunities for students who have other daytime responsibilities. Cooke (2010) goes on to argue that creating an adult-centered learning environment during library instruction 


\section{LEVERAGING ADULT LEARNING THEORY WITH ONLINE TUTORIALS}

sessions can reduce the amount of library- and technology-related stress many adult learners experience.

\section{Andragogy and online learning}

Unsurprisingly, the same techniques used to engage adult learners are similar to ones to engage online or distance learners (Rossman, 2000); after all, more and more adults are turning to online education for their degrees. Though they don't necessarily use the terms andragogy nor adult-centered learning, much of the pedagogical best practices for online instructional design take a constructivist or self-directed learning approach. Best practices for online learning environments include making lessons highly relevant to the students' work or education goals (Park and Choi, 2009), establishing opportunities for both collaboration and reflection (Tsai, 2013), and engaging students through problem-based exercises (Cheaney and Ingebritsen, 2005). As another example, "gaming" library instruction is a growing trend in online library environments and supports andragogy principles (Kim, 2012). Game theory and other gaming strategies allow students to work at their own pace and inspire curiosity, and apply information literacy skills directly to a course's learning objects (Martin and Ewing, 2008; Kim, 2012). Furthermore, instruction librarians are beginning to incorporate components of online instruction that supports multiple styles of learning to better reflect the diverse age, experience, and technological comfort levels of the student population (Scales, Nicol, and Johnson, 2014). Finally, Allen (2008) argues that through a scaffolded constructivist approach, digital learning objects can be instrumental in promoting critical and information literacy skills.

While there is a large body of literature on engaging the adult learner in the library instruction classroom, little of it focuses on how to translate andragogy into asynchronous online learning objects; similarly there is a growing body of literature that proposes pedagogical 
frameworks for digital or online learning objects, though not necessarily geared towards adult users. The apparent lack of literature that marries the two related instructional strategies seems like an oversight considering many adult learners are earning their degrees online. This paper, and the project as a whole, attempts to address this gap in knowledge.

\section{Information Literacy Toolkit}

Inspired by Portland State University's Library DIY (http://library.pdx.edu/diy/) and the The Manchester University Library’s Learning Essentials (http://www.library.manchester.ac.uk/academicsupport/mylearningessentials/), the librarians for the School of Social Work and the Annenberg School for Communication and Journalism wanted to build a similar set of learning modules for our online students. At the time, there were a handful of tutorials that librarians had designed and that were used for instruction, they were mostly comprised of screencasts and lecture-type videos. The authors wanted tutorials that were interactive, modular, and pedagogically sound. First, the new tutorials needed to be created in a software that would allow many types of interactions, like drag-and-drop activities, multiple choice questions, user-driven animations, and text entry to allow for reflection. After consulting with a number of our librarian colleagues, and reaching out to the librarians responsible for My Learning Essentials, the authors decided to purchase Articulate Storyline (https://www.articulate.com/products/storyline-why.php). This e-learning authoring software is fairly easy to use, has many types of interaction and quizzing options, and can be published directly to the library website or embedded in a learning management system. Thanks to the USC Libraries Dean's Challenge Grant, the authors purchased two licenses of this software.

The authors then spent several weeks considering how the tutorials would ideally be used. Did we want them to sit on the library's website for students to use as they wished? Or did 


\section{LEVERAGING ADULT LEARNING THEORY WITH ONLINE TUTORIALS}

we want the instruction librarians to use them as a tool for flipping the classroom? Or did we want discipline faculty to assign tutorials as assignments? Ideally, the short answer was: all of the above. Realistically, we decided that the most utility would come from our teaching faculty embedding them into the curriculum and instruction librarians using them as active learning tools. Indeed, the concept of these tutorials as tools led to the name of the collection of tutorials: the Information Literacy Toolkit, as the tutorials as a whole would be a collection of tools that could serve many purposes.

The Toolkit has a modular design and is comprised of three overarching subjects: developing a search strategy, finding resources, and using resources. There are then five or six individual tutorials within each topic; for instance, in developing a search strategy are tutorials on articulating a research question, identifying keywords, and knowing where to conduct a search. Eventually, the tutorials page on the library website will host each tutorial in its category so students and librarians can easily locate the tutorials they need.

The most important consideration for the Toolkit was that each tutorial be aligned with the principles of adult learning theory. In the next section, this paper will describe how each of the four principles of andragogy applied, or didn't apply, to the Toolkit tutorials in order to make them adult-centered.

\section{Principle \#1: Adult-centered tasks are highly relevant to a problem}

Adult students need instruction to be at point-of-need and highly relevant to a task. Adult education scholars have found that adult learning is most easily facilitated when "learning activities are deemed to have some relevance or utility to the learners' circumstance" (Currie, 2000, p. 222). For social work and journalism students, whom likely will not have careers in research, framing the library tutorials within a required skill set is key. The authors did this both 


\section{LEVERAGING ADULT LEARNING THEORY WITH ONLINE TUTORIALS}

in the structure of the tutorials themselves, and through the strategic placement of the modules within the curriculum and various digital learning objects. Each tutorial opens with a small story that helps frame the concept covered in that tutorial; the story is usually an example of a situation where a fictional student encounters difficulties completing an assignment because the student doesn't yet have the skills developed in the tutorial. Clark and Rossiter (2008) argue that storytelling and narrative-building are very powerful learning tools, and allow students to put themselves in the middle of the problem. The use of a short story at the beginning of the tutorials lets students better understand why a certain concept or set of skills is useful or necessary to them. As an example, in the Knowing Where to Look tutorial, a fictional student spends hours looking for Department of Justice statistics in a scholarly database because he doesn't realize those statistics can easily be found on the Department's website. Framing each lesson in a scenario like this helps students "know why the need to learn something before undertaking to learn it" (Knowles, 1984, p. 55).

By placing particular tutorials as part of research-based course assignments throughout the semester, students are developing relevant skill sets when they need them. Students in the research course in the School of Social Work, for example, complete the Developing Keywords tutorial before the in-class library session as they work on their first literature review assignment. Similarly, linking to particular tutorials in strategic places on a LibGuide, including them in reference interactions, or making them easily searchable on the Libraries' website are other ways to embed the tutorials to optimize their relevancy for adult students.

\section{Principle \#2: Adult-centered instruction is problem-based}

Problem-based learning is an experiential, constructivist learning approach that "has its roots" at the McMaster University School of Medicine as far back as the 1960s (Albanese and 


\section{LEVERAGING ADULT LEARNING THEORY WITH ONLINE TUTORIALS}

Mitchell, 1993, p. 52). Problem-based learning posits that when students are allowed to explore solutions to problems independently, rather than being told the answer, they are better able to explain and integrate concepts into decision-making processes (Capon and Kuhn, 2010). The role of the instructor in problem-based learning is to design appropriate and sufficiently complex problems for students to solve, and to facilitate communication that encourages students to disagree, form conclusions, and meet specified learning objectives (Wood, 2003). In an inperson library session, problem-based learning techniques are typically achieved through strategies of authentic assessment and active learning (Ross and Furno, 2011). In the online, asynchronous environment, the Toolkit tutorials model problem-based learning through activities.

One of the characteristics of a problem-based lesson is the role of the instructor as a facilitator (Wood, 2003). Instead of lecturing to deliver content, the instructor sets up problems for students to solve, either independently or collaboratively. In the tutorials, there are very few slides that do not have an activity to complete or problem to solve. As a general rule, each slide has no more than about a paragraph of any kind of explanatory text; instead, students complete exercises, reflect on how those exercises develop a particular skill, and receive feedback to reinforce those connections. In fact, the primary reason Articulate Storyline was chosen for these tutorials was for the variety of interactions and problem types it offers. In the Developing Keywords tutorial, students are prompted to experience how search results change as a result of different keywords and consider why that is before the tutorial delivers an explanation. Similarly, in the Avoiding Plagiarism tutorial, students are given a brief introduction to when citations are required in academic writing, and are then asked to identify where in a given 


\section{LEVERAGING ADULT LEARNING THEORY WITH ONLINE TUTORIALS}

passage plagiarism has occurred in order to reinforce the material and provide immediate feedback on the mastery of that skill.

\section{Principle \#3: Adult-centered instruction acknowledges the learners prior experiences}

Knowles states, "the richest resources for learning reside in the adult learners themselves" and hence, techniques that "tap into the experience of the learners" are preferential over "transmittal techniques" (1984, p. 57). Admittedly, this is the principle of andragogy that is most difficult to apply to asynchronous environments, as some techniques for acknowledging learners' experiences are through think-pair-share activities and discussion-based exercises. In the Toolkit, learners have an opportunity to reflect on their experiences and apply them to the information literacy concept being covered. For example, in the Evaluating Sources tutorial, students are asked to reflect on the qualities of a good employee. The qualities they record are later used in the tutorial to connect qualities of a good employee to those of a good information source. Opportunities to reflect on work or life experiences throughout the tutorial can help transform the tutorial's content into new knowledge or dispositions (Cercone, 2008).

\section{Principle \#4: Adult-centered instruction is self-directed}

Knowles warns adult educators that adult learners have an established self-concept of being responsible, independent, and self-directed adults. This self-concept can sometimes come into conflict with formal education, as so much of the education system is designed with the assumption that learners are passive receivers of information (Knowles, 1984, p. 56). Knowles and other prominent education theorists advise instructors to facilitate the transformation of adult learners from passive receivers of knowledge to self-directed creators of meaning (Knowles, 1984, p. 57). Self-directed learning is a strategy that applies that advice. Self-directed learning (SDL) posits that the primary goal of instruction is to facilitate the development of independent 


\section{LEVERAGING ADULT LEARNING THEORY WITH ONLINE TUTORIALS}

learners, which requires learners to take responsibility for their own education (Merriam, 2001). In the Toolkit, SDL is manifested through navigation options. Some of the tutorials cover a lot of material, from a basic introduction to complex applications. Students are using and interacting with the tutorial in different points of their research process, and are entering the academic research world with variable existing skill sets and dispositions. Thus, it is important that these tutorials can be welcoming to any student; those who are more advanced can skip right to the more complicated material, while students who need an introduction are able to start from the beginning if they wish. Students are free to use the menu to jump around to only tackle the concepts they need and they can easily navigate to the learning domains of their choice. Having an easy-to-navigate menu and not making any section required in order to move on to different sections allows students to set their own learning goals and address the content that is useful to them, meeting the SDL goal of facilitating a self-directed learning process (Merriam, 2001, p. 9).

\section{Discussion}

This paper addressed how information literacy tutorials can be more engaging and meaningful for nontraditional students by aligning them with the principles of adult learning theory. As adults continue to take advantage of the flexibility online education affords them, librarians must become proficient in reaching the unique needs of those students. Adult learning theory follows four primary principles that can be applied to nearly any digital learning object; one doesn't need expensive software or a formal background in instructional design to ensure that tutorials are acknowledging the learner's experience, highly relevant, problem-centered, and self-directed.

Admittedly, the Information Literacy Toolkit is still in its infancy, with half of the tutorials completed to date (5 of 10) and thus cannot yet be evaluated for its efficacy. The 


\section{LEVERAGING ADULT LEARNING THEORY WITH ONLINE TUTORIALS}

tutorials are currently providing informal feedback in the form of optional end-of-tutorial surveys. The survey asks the students about the pacing, navigation, and level of content, as well as how they heard about the tutorial and what other topics they'd like to see covered in this format. To date, the responses have been overwhelmingly positive, with a majority of students who responded (94\%) indicating that both the level of the content and the pacing was "just right," with a few (less than 1\%) noting that the tutorials seem "too beginner" for their needs. The response rate on these end-of-tutorial surveys are very low, with less than $1 \%$ of the unique pageviews for the tutorials generating feedback. Once a majority of the tutorials have been created, the authors will conduct a multi-step assessment consisting of student focus groups and surveys from both students and teaching faculty. The results of the assessment will inform the future direction of the Toolkit. Perhaps the tutorials need to be longer and offer more practice exercises to develop proficiency in the skill; on the other hand, perhaps the tutorials are too basic and aren't encouraging the level of critical thinking or problem-solving required for advanced courses. The authors are looking forward to structured feedback in hopes to provide evidencebased best practices for our university and professional colleagues. These results will shape the structure and content of future tutorials.

The primary mode of marketing the Toolkit is through librarian outreach. Every time a new tutorial is developed, the authors send an email to the student and faculty listservs to promote them. The Social Work librarian also sends emails to individual instructors if assignments in their courses relate to any of the modules and suggests including specific tutorials in the weekly readings or assignments. To date, at least one tutorial is included as a required or recommended activity in 4 of the 7 required foundation courses for the Master of Social Work program. Indeed, the majority of visitors (89\%) who provide feedback arrive as a result of a 


\section{LEVERAGING ADULT LEARNING THEORY WITH ONLINE TUTORIALS}

course requirement or instructor recommendation. Of course, the tutorials can also be found on the libraries' tutorials website, and a small handful of tutorial users report finding them through the site. Upon the completion of the Toolkit, we will host a session for all instruction and reference librarians at our university to promote and interact with the Toolkit, so that they can use them in their instruction sessions or suggest them to teaching faculty in their disciplines.

\section{Conclusion}

Online education for adult learners is not just a passing trend - it proves to be a meaningful and important way for adults to continue their education. Libraries are places of support for the nontraditional student, and as such, many of our learning objects must be designed with these students in mind. Creating online tutorials and other digital learning objects framed in adult learning theory is an easy and powerful way to reach this oft-underserved and dynamic student population.

While the tutorials that make up the Toolkit are created with a relatively expensive software, any library can orient their online tutorials towards the adult learner. Keeping in mind the characteristics of adult learners, that they are highly motivated and ready to learn, that they want their life experiences acknowledged, that they want to be self-directing in their education, and they need to know the relevance of a lesson to their goals, is the first step to creating an adult-centered online learning environment. Establishing andragogical best practices in asynchronous library tutorials is a step towards ensuring the library is safe, welcoming, and transformative place on the journey towards a love of lifelong learning. 


\section{LEVERAGING ADULT LEARNING THEORY WITH ONLINE TUTORIALS}

\section{References}

Albanese, M. A., and Mitchell, S. (1993), "Problem-based learning: a review of literature on its outcomes and implementation issues", Academic Medicine, Vol. 68 No. 1, pp. 52-81. doi:10.1097/00001888-199301000-00012

Allen, I. E., and Seaman, J. (2011) Going the distance: online education in the United States, 2011, Sloan Consortium, Newburyport, MA.

Allen, M. (2008), "Promoting critical thinking skills in online information literacy instruction using a constructivist approach", Part of a Special Issue on Critical Thinking within the Library Program, Vol. 15 Nos. 1/2, pp. 21-38. doi:10.1080/10691310802176780

American Council on Education (2014), "Nontraditional students", available at: http://www.acenet.edu/higher-education/topics/Pages/Nontraditional-Students.aspx (accessed 2014 August 8).

Anderman, E.M., and Anderman, L.H. (Eds.) (2009). Constructivism, in: Psychology of Classroom Learning: An Encyclopedia, Macmillan Reference USA, Detroit, pp. 262-274.

Arif, M. and Mahmood, K. (2012), "The changing role of librarians in the digital world", The Electronic Library, Vol. 30 No. 4, pp. 469-479, doi: 10.1108/02640471211252184

Bichsel, J. (2013). The State of E-learning in Higher Education: An Eye Toward Growth and Increased Access, EDUCASE Center for Analysis and Research, Louisville, CO.

Bowles-Terry, M., Hensley, M. K. and Hinchliffe, L. J. (2010), "Best practices for online video tutorials in academic libraries", Communications in Information Literacy, Vol. 4 No. 1, pp. 1728.

Buehler, M., Dopp, E., Hughes, K.A. and Thompson, J. (2001), "It takes a library to support distance learners", Internet Reference Services Quarterly, Vol. 5 No. 3, pp. 5-24.

Burns, S., Cunningham, J. and Foran-Mulcahy, K. (2014), "Asynchronous online instruction: Creative collaboration for virtual student support", CEA Critic, Vol. 76 No. 1, pp. 114-131. doi:10.1353/cea.2014.0007.

Capon, N. and Kuhn, D. (2004), "What's so good about problem-based learning?", Cognition and Instruction, Vol. 22 No. 1, pp. 61-79.

Cercone, K. (2008), "Characteristics of adult learners with implications for online learning design", AACE Journal, Vol. 16 No. 2, pp. 137-159. 


\section{LEVERAGING ADULT LEARNING THEORY WITH ONLINE TUTORIALS}

Cheaney, J. D., and Ingebritsen, T. (2005), "Problem-based learning in an online course: A case study", The International Review of Research in Open and Distance Learning, Vol. 6 No. 3.

Clark, M. C. and Rossiter, M. (2008), "Narrative learning in adulthood", New Directions for Adult and Continuing Education, Vol. 2008 No. 119, pp. 61-70. doi:10.1002/ace.306

Currie, C.L. (2000), "Facilitating adult learning: The role of the academic librarian", The Reference Librarian, Vol. 33, pp. 219-231.

Cooke, N. A. (2010), "Becoming an andragogical librarian: Using library instruction as a tool to combat library anxiety and empower adult learners", New Review of Academic Librarianship, Vol. 16 No. 2, pp. 208-227.

Gold, H. E. (2005), "Engaging the adult learner: Creating effective library instruction”, Portal: Libraries and the Academy, Vol. 5 No. 4, pp. 467-481.

Gonzales, B.M (2014), "Online tutorials and effective information literacy instruction for distance learners", Journal Of Library \& Information Services In Distance Learning, Vol 8 No. 1/2, pp. 45-55.

Hansen, M.A. (2003), "The land grant university reference librarian of the $21^{\text {st }}$ century", in Bridges, K. (Ed), Expectations of Librarians in the $21^{\text {st }}$ Century, Praeger Publishers, Connecticut, pp. 1-5.

Julien, H. and Pecoskie, J.L. (2009), "Librarians' experiences of the teaching role: Grounded in campus relationships", Library and Information Science Research, Vol. 31 No. 3, pp. 149-154.

Jumonville, A. (2014), "The role of faculty autonomy in a course-integrated information literacy program", Reference Services Review, Vol. 42 No. 4, pp. 536-551. doi: 10.1108/RSR-07-20140020

Kim, B. (2012), "Harnessing the power of game dynamics: Why, how to, and how not to gamify the library experience", College \& Research Libraries News, Vol. 73 No. 8, pp. 465-469.

Knowles, M. S. (1984), The Adult Learner: A Neglected Species, $3^{\text {rd }}$. edn, Gulf Publishing Company, Houston, TX.

Larreamendy-Joerns, J. and Leinhardt, G. (2006), "Going the distance with online education", Review of Educational Research, Vol. 76 No. 4, pp. 567-605.

Martin, J. and Ewing, R. (2008), "Power up! Using digital gaming techniques to enhance library instruction”, Internet Reference Services Quarterly, Vol. 13 No. 2-3, pp. 209-225.

Massis, B.E. (2012), "Librarians and faculty collaboration - partners in student success", New Library World, Vol. 113 No. 1/2, pp. 90-93. 


\section{LEVERAGING ADULT LEARNING THEORY WITH ONLINE TUTORIALS}

Merriam, S. B. (2001), “Andragogy and self-directed learning: Pillars of adult learning theory”, New Directions for Adult and Continuing Education, Vol. 89, pp. 3-14.

Miller, R. T. (2014), “Online learners \& libraries”, Library Journal, Vol. 139 No. 16, p. 8.

Newby, J., Eagleson, L. and Pfander, J. (2014), "Quality matters: New roles for librarians using standards for online course design", Journal of Library \& Information Services in Distance Learning, Vol. 8 Nos. 1-2, pp. 32-44.

Ota, C., DiCarlo, C. F., Burts, D. C., Laird, R., and Gioe, C. (2006), "Training and the needs of adult learners", Journal of Extension, Vol. 44 No.6.

Parker, K., Lenhart, A., and Moore, K. (2011), "The digital revolution and higher education", available at: http://www.pewsocialtrends.org/2011/08/28/the-digital-revolution-and-highereducation/ (accessed 2014 August 8).

Rapchak, M., and Behary, R. (2013), "Digital immigrants, digital learning: Reaching adults through information literacy instruction online", Journal of Library \& Information Services in Distance Learning, Vol. 7, pp. 349-359.

Ross, A., and Furno, C. (2011), "Active learning in the library instruction environment: An exploratory study", Portal: Libraries and the Academy, Vol. 11 No. 4, pp. 953-970.

Rossman, M. H. (2000), “Andragogy and distance education: Together in the new millennium”, New Horizons in Adult Education and Human Resource Development, Vol. 14 No. 1, pp. 4-11.

Scales, B. J., Nicol, E. and Johnson, C. M. (2014), "Redesigning comprehensive library tutorials: Theoretical considerations for multimedia enhancements and student learning", Reference \& User Services Quarterly, Vol. 53 No. 3, pp. 242-252.

Shupe, E.I. and Pung, S.K. (2011) "Understanding the changing role of academic librarians from a psychological perspective: A literature review", The Journal of Academic Librarianship, Vol. 37 No. 5, pp. 409-415. doi:10.1016/j.acalib.2011.06.005

Sun, H., Chen, K., Tseng, C. and Tsai, W. (2011), "Role changing for librarians in the new information technology era", New Library World, Vol. 112 No. 7/8, pp. 321-333. doi:10.1108/03074801111150459

Viggiano, R. G. (2005), “Online tutorials as instruction for distance students", Internet Reference Services Quarterly, Vol. 9 No. 1-2, pp. 37-54.

Walter, S. (2008), "Librarians as teachers: A qualitative inquiry into professional identity", College \& Research Libraries, Vol. 69 No. 1, pp. 51-71. 


\section{LEVERAGING ADULT LEARNING THEORY WITH ONLINE TUTORIALS}

Wood, D. F. (2003), “ABC of learning and teaching in medicine: Problem based learning”, BMJ : British Medical Journal, Vol. 326 No. 7384, pp. 328-330.

Wyss, P.A., (2008), "Getting started as distance learning librarian", College Student Journal, Vol. 42 No. 2, pp. 440-448.

Zhang, W., Perris, K. \& Yeung, L. 2005, "Online tutorial support in open and distance learning: students' perceptions", British Journal of Educational Technology, Vol. 36, No. 5, pp. 789-804.

\section{Acknowledgments:}

We would like to thank the USC Libraries' Dean's Challenge Grant for funding for the Articulate Storyline software, without which, this project would still just be a big idea. 